\title{
The University of Melbourne
}

\author{
Suzanne Hermanoczki
} Remembering and Rewriting the Familial Traumascape in Alice Pung's memoir
Her Father's Daughter

\begin{abstract}
:
Often in immigrant literature, the familial landscape or homeland is considered a traumascape, which as Maria Tumarkin explains, is a place 'marked by traumatic legacies of violence, suffering and loss' (2005: 12). For many first-generation immigrants and refugees forced into leaving their homelands, the familial traumascape is also trapped in a past that no longer exists, or exists only in memories that are subject to traumatic 'visual and sensory triggers' (Tumarkin 2005: 12). This paper will show how second-generation immigrant writer Alice Pung has used her father's firstgeneration trigger memories of place in her memoir Her Father's Daughter (2011) to direct her own writing. A textual analysis of the father's present day narrative will reveal details of the traumatic events of an unliveable homeland and the intergenerational impact of this familial traumascape on his daughter. It will also discuss how, at the heart of Her Father's Daughter, is the Barthesian idea of the punctum and its connection with testimony; and how the father's homeland or familial landscape becomes the traumatic wounded site of painful trigger memories. Examining the writing from the site of the wound, this paper shows how the father's traumatised memories of his homeland are able to be transformed as postmemories of place and belonging for the second-generation/daughter in her memoir.
\end{abstract}

\section{Biographical note:}

Dr Suzanne Hermanoczki is a writer and teacher of fiction and creative non-fiction. She holds a $\mathrm{PhD}$ in Creative Writing from The University of Melbourne. Her current fictional novel-in-progress won The University of Melbourne's Affirm Press Creative Writing Prize (2014). Her writings on place and identity, mixed code and bi-ethnicity and multiculturalism, have appeared in both local and international publications.

\section{Keywords:}

Creative Writing - Alice Pung - Her Father's Daughter - Postmemory - Traumascape - Memoir 


\section{Remembering \& Rewriting the Familial Traumascape in Alice Pung's memoir Her Father's Daughter}

The idea of postmemories and the familial traumascape are examined in Alice Pung's memoir Her Father's Daughter (2011) for their role in intergenerational immigrant narratives. For memory researcher Aleida Assmann, the term 'intergenerational' is based on the concept of 'memorial transmission' where the familial transfer of past events become an 'embodied experience [for] the next generation' (Hirsch 2012: 32). Analysis of Pung's work and related literature demonstrate how 'the familial traumascape', a term inspired by Marianne Hirsch and Maria Tumarkin, can also serve as a testimonial object. As a testimonial object, the traumatised homeland becomes a powerful '[point] of memory' (Hirsch 2012: 22), one that enables remembrance, familial connection by providing an 'intersection between past and present, memory and postmemory, personal and cultural recall' (Hirsch and Spitzer 2012: 61). The textual analysis will show how events experienced in the familial traumascape are transferred from one generation to the next via trigger memories of fragmented testimony, or as 'dismemories', which is a word Pung uses in reference to her father and the memories he 'had deliberately forgotten to remember' (2011: 191). ${ }^{1}$ In Pung's intergenerational work, the father's dismemories are passed on as testimonial fragments and witnessed by the second-generation the daughter/Alice, and transformed into postmemories in her search for her own identity and narrative.

\section{Trauma and Postmemory}

The trauma experienced by the first-generation is a constant presence for the daughter/narrator/Alice in her memoir, Her Father's Daughter (Pung 2011). Growing up in Australia, the daughter is witness to her Cambodian father and other firstgeneration immigrant survivors' 'suffering' and 'pain' (Hron 2009: 27). Her father and her Cambodian community's collective trauma have impacted Alice's own memories to the point where her life has been defined and 'dominated' by the postmemories of the unspoken 'narratives that preceded [her] birth' (Hirsch 2012: 5). The memoir reflects how Alice's own story has been and continues to be 'shaped ... indirectly, by traumatic fragments of events that ... defy narrative reconstruction and ... comprehension' (Hirsch 2012: 5). ${ }^{2}$ Although Hirsch's research into postmemory primarily focusses on the Holocaust as the historical frame of reference and the impact of memory on survivors, her work extends and recognises other historical global events and cultural groups such as the Cambodian who witnessed the genocide of their own people (2012: 18-19). ${ }^{3}$ Of such a traumatised cultural group, Hirsch understands the intergenerational transmission of trauma on subsequent generations, and the second or postgenerations' like Pung's inherent desire to learn about the 'horrific, unknown, and unknowable past that their parents were not meant to survive' and their own need to represent it through 'fiction, art, memoir, and testimony' (Hirsch 2012: 34). Pung's work is a response to the memoir and testimony Hirsch is referring to - of a second-generation immigrant's attempt to understand the past and to 'represent the long-term effects of living in close proximity to the pain, depression, 
and ... persons who have witnessed and survived massive historical trauma' (Hirsch 2008: 112).

Right from the memoir's opening scene 'Stay and Defend' in the Prologue to Her Father's Daughter (Pung 2011: 3), Pung's sixty-year old father Kuan, is shown anticipating his daughter, Alice's, return home after months of living and writing in China. ${ }^{4}$ At first, the father seems to understand his daughter's need to write, yet his feelings and reasoning of her being abroad shifts dramatically as he experiences what can be described as 'chronic anxiety' (Krystal 1995: 76) when he begins expressing his fears for her safety. ${ }^{5}$ In this scene, he becomes so distressed by their separation and the distance he concludes by stating how he sees no point of her leaving home in the first place: 'If she wants to write, then he will give her stories. Why did she need to go overseas to find them?' (Pung 2011: 4).

In contrast, the daughter's opening story 'Far from Home' sees the writer/narrator Alice, resigned to the fact that she needs to clarify her father's exaggerated 'fears'(2011: 6) for her safety while abroad. She begins by explaining his obsession with 'bad things happening' to her, and starts listing other similar fear-induced conversations, like how to flee from danger: Father- '[y]ou save yourself ... That is all' (2011: 6-7). The daughter also shares personal insights into what it is like to live with such knowledge of trauma, 'because Mum, like Dad, had been through this before. They knew what to do' (2011: 7). She describes what it was like growing up with likeminded 'survivors'; 'weary-looking men and women ... who did things that didn't involve much talking', who lived through 'the Black Bandits' and 'didn't talk about these things [such as their past] with people who would never understand' (Pung 2011: 7). ${ }^{6}$ At this point, it is clear the daughter has not directly asked her father or her community about what occurred in their/her familial homeland, Cambodia. In fact, she seems reluctant to learn what is at the 'core ... to that truth' (Laub in Hirsch 2012: 75). What is apparent however, is her awareness of the traces of trauma affecting these survivors: as it was 'a question that did not need an answer: [it] was right in front of their faces, in the breath that came in and out' (Pung 2011: 7).

\section{Trigger Memories and Testimony}

Pung's memoir Her Father's Daughter begins a few years after her first book, Unpolished Gem. Published in 2006, Unpolished Gem (also a memoir) documented Pung's everyday life as a Chinese-Cambodian teenager of immigrant parents growing up in suburban Footscray, Australia. ${ }^{7}$ Her Father's Daughter signals a clear departure from adolescence, and expresses this transition through its narratorial voice and the work's overall adult tone and themes. The memoir opens with Pung as a young woman and her life in present day Melbourne. It details events from her work in a law firm, her travels overseas to China and Macau and her failed attempt to write about her ancestral 'homeland' China, her experiences with love and her first romantic relationship as an adult, as well as moving out of home and into the residences in Janet Clarke Hall at the University of Melbourne, all while still pursuing a career in writing. Her contemporary story runs in parallel with her father's immigrant story - 
the new life he has established in Footscray, Melbourne with his wife Kien and his family, and his job as manager of an electrical goods store.

Interrupting throughout the father's narrative however, are his continued and recurring 'fears' for his children, in particular what could happen to his daughter, Alice. As his present story is retold, it is pierced with intermittent 'blinding flashes' of his past and of the 'unimaginable apocalyptic hell' (Pung 2012: 47) he experienced in his home country. Despite trying to erase and supress his past, the father in his day-to-day life in Australia often unconsciously or psychosomatically displays the trauma he experienced in the old homeland either via nightmares, fragmented memories, actions, and behaviour or when recalling objects and places. Hirsch and Leo Spitzer explain that certain objects can act as memory triggers and as points of intersection, 'testimonial objects', and I will add here places too, are able to 'traverse temporal [and] spatial ... divides' (Hirsch and Spitzer 2012: 61-62) to reveal trauma and show how the past is still able to affect the present and subsequent generations.

Though the daughter is focussed on retelling her story, she often finds herself overshadowed by her father and his behaviour. In one particular passage, she writes how 'irrationally annoyed at him' she feels, but in the following sentence she is conflicted about her 'gnawing guilt over this anger' (Pung 2011: 93). This sentiment is revealed in a scene where her parents are to come to Ormond College to hear her talk about Unpolished Gem. However, the comfort of having them in the audience soon becomes fraught with anxiety the moment she receives news from her father that her mother Kien has caught the wrong tram and is lost. Though this detail is not significant to the talk's organisers nor the audience, Kien's absence and her father's increasing 'anxiety' (Krystal 1995: 80) for his wife's safety escalates, and sends him into 'panic disorder personified' (Pung 2011: 92). ${ }^{8}$ When Alice gets up to give her speech, she suffers an attack of the 'jitters' as all she can think about is her father and his 'panic' which had 'permeated everything so nothing was normal anymore. His fear was casting shadows on her newly built white middle-class existence and making her walls crack loose like chalk' (2011: 93). Even after they both hear that Kien is safely on her way back home, her father's fears have affected her to the point that: 'She had to sit down. Her legs were shaking behind the wooden lectern' (2011: 93).

Psychiatric examiner on Holocaust survivor behaviour, Henry Krystal, in his seminal article 'Trauma and Aging: A Thirty-Year Follow-Up' (1995), explains the effects of psychic trauma on aging adult survivors, and describes that they can,

show signs of the continuation of the trauma patterns, hypervigilance, anxiety dreams, sometimes a driven need to talk about the events of the traumatic period, at other times a need to avoid doing so. (81)

Perhaps provoked by the psychosomatic effects of this incident, the daughter begins recalling other similar patterns displayed by her father, mother and community, and links their collective behaviour back to past events and place which has never actually been explained to her. Driven by the need to comprehend her/his/their ongoing distress, she realises that the past needs to be told and so asks her father to let her speak to survivors in her community, which he agrees to: 


\section{Father-}

'If you want to know about the time of Pol Pot, I will introduce you to people,' her father told her ... 'and they will talk to you and tell you about their lives.'

He took her to visit his friends in suburban houses with neat front yards in Footscray and Springvale, and they would tell her tales of survival. She remembered these moments, how at some pivotal point these older folk began to speak to her as if they no longer saw her as a child but as someone who would store these stories, and who might one day convey them to their own progeny ... (Pung 2011: 110-111)

The more the daughter listens to 'these older folk' (2011: 111) and bears witness to their survivor testimonies, she begins to realise the importance of knowing about the past and the role she has as a writer and in their re-telling. ${ }^{9}$

Dori Laub, a psychoanalyst for trauma survivors, and child Holocaust survivor from Czernowitz, defines 'testimony' as 'the process by which the narrator (survivor) reclaims his position as a witness' (1995: 70). The process which Laub discusses in a recent interview with Cathy Caruth in Listening to Trauma (2014), involves more than a survivor simply telling their story, a listener must also be present in creating an imaginative place for trauma so that in the process of transmission it becomes a witnessed story ... a narrative' (Laub in Caruth 2014: 58). As Laub explains, 'if you allow it, if you can help it, an extraordinary narrative is forthcoming' (2014: 72).

As Alice listens to the survivors in her community, she is transported to the time, place, and source of her familial trauma, where she becomes a witness to the past. In accessing their testimonies, she realises that her story lies within her community and that it is as much her father's story as it is hers. By recognising the importance of bearing witness, she arrives at a place of mutual understanding between herself and the older generation of survivors who had begun to regard her not 'as a child but as someone who would store these stories' (Pung 2011: 111). Yet it is while she is listening to one particular survivor's testimony that she starts to question certain inexplicable details within the narrative:

\section{Daughter-}

The bus, the man said. It loaded us on, and then it took us to the top of a mountain and dumped us there ... [it] was dotted with landmines. At the top there was no food or water, so we went down and exploded and died ... But the man was sitting in front of them, telling this story so obviously he had not died ... (2011: 111-112)

After this recount she asks: 'Who was the first at the top of the mountain to start worrying ... and the first to make their way down?' (112). Even though she 'may never [truly] know what happened' (Pung 2011: 112), there exists a personal need to understand and get close to the 'real event [and the] real truth for both of them' (Laub 2014: 75). The incident becomes a turning point, in her decision to journey to the homeland and write of the events and of the place where 'the genocide happened' (Hirsch 1997: 243). 


\section{Traumascapes}

In her ground breaking work Traumascapes (2005), academic, writer and historian Tumarkin defines trauma 'not [as] a medical condition or a pathological state but an individual and collective response to loss and suffering - an ongoing response that affects people at their very core' (13). Tumarkin in her work analyses landscapes and places in the same way; how they can be similarly affected through the devastations of war, bombings, mass killings and political upheaval, thereby transforming a site or landscape into a traumascape:

Full of visual and sensory triggers, capable of eliciting a whole palette of emotions, traumascapes catalyse and shape remembering and reliving of traumatic events. It is through these places that the past, whether buried or laid bare for all to see, continues to inhabit and refashion the present ... (Tumarkin 2005: 12)

She argues how people 'need places to deal with unexpected, violent tragedies', but also how they are compelled to return and mark these sites in order to mourn and make meaning of them (sic 2015: 151). Madelaine Hron author of Translating Pain: Immigrant Suffering in Literature and Culture (2009) also focusses on trauma but within the genre of immigrant literature. Hron describes the act of leaving one's home, country of origin, birthplace or town, as a traumatic act of separation, explaining how pain or trauma can occur the moment people leave their country but also when the familial landscape is remembered, especially if '[s]uffering ... result[ed] from traumatic events ... such as violence, persecution, or war' (2009: 27).

Considering these factors, readers must be reminded that Pung's father Kuan, was a refugee forced to 'flee' his home country due to 'war' and 'life-threatening ... political conditions' (Hron 2009: 7). For Kuan, recalling the familial traumascape and revisiting Cambodia also signals confronting the 'punctum' (Barthes 1981: 26) and the site of the 'wound' of his unarticulated memories and latent psychic trauma. ${ }^{10}$ Roland Barthes explains that the punctum, in relation to photographs, is the site that is able to pierce and wound the viewer. Hirsch and Spitzer extend this notion of the punctum to testimonial objects stating they puncture memory 'interpellating those who seek to know about the past' (2012: 61). It is only by returning to the traumascape of the Killing Fields that the daughter will hear her of father's traumatic testimony and in turn know her own story and process the questions raised by the other survivors.

\section{The Cambodian Traumascape}

The memoir's crux occurs in 'Part III. Cambodia: Year Zero' of Her Father's Daughter (Pung 2011: 113). Changing in perspective and style, the third section starts with the re-telling of the story of Saloth Sar: 'In the beginning there was a man and a bowl ... He would go from door to door, and people would give him food. No one called him a beggar, they called it giving alms' (2011: 115). The character Saloth Sar is in fact Cambodian Khmer Rouge leader Pol Pot, and 'Year Zero' a reference to the moment he declared his people 'were to start the world anew' (2011: 116). Under Pol Pot's regime, the population and their past would be 'wiped out, their minds blown clean and taut and soaring like balloons' and '[t]hose who couldn't wipe their minds hard or fast or clean enough would be popped' (2011: 116), in other words, killed. In 
contrast to his rise to power, is the narrative of a small boy, Kuan (Alice's father), who grows up in the capital city Phnom Penh; the son of wealthy Chinese factory owners who 'knew nothing of the man who came before, and who was to come into his world and turn it inside-out' (2011: 117).

The section is a postmemorial re-telling of the father's story or 'testimony'; describing his upbringing, his comfortable life as a boy, his family's work as factory owners, right up to the moment his old life changed when Pol Pot assumed power. Detailed in the scenes that follow is Kuan's forced evacuation from Phnom Penh and his relocation to the work camps in the outlying villages. His narrative documents three difficult years of camp life, where as a prisoner he witnesses the horrific mistreatment of his people including starvation, torture and executions. He recounts his own degradation in his role of making fertiliser out of human excrement; where his ability to re-tell proving 'a testament to the power of memory and continuity in the face of brutality and dehumanization' (Hirsch and Spitzer 2012: 178). In his recollection, Kuan details how:

[h] is team would collect the shit and mix it with water to make wet fertiliser for the vegetables ... He marvelled that a dying cluster of people could still create life from their bodies, could make things grow even though they were being eaten away by hunger. (Pung 2011: 155)

Yet his strongest memories are tied to the site where he buried the dead in the fields. It is at this site of trauma that the landscape is transformed into the punctum working as a testimonial object allowing for 'memory and transmission' (Hirsch and Spitzer 2012: 61-62).

After three years of internment and with the fall of Pol Pot's regime, Kuan and his family decide to flee Cambodia into Vietnam. In 'After Zero: Saigon, 1979', Kuan meets 'his future wife Kien (Alice's mother) in Saigon' (Pung 2011: 181) and marries her. But due to political instability in the region, they are forced to leave Vietnam. Kuan and Kien escape through the jungles and enter into the Red Cross camps 'run by the UN at the Thai border which allowed Cambodian and Vietnamese refugees get into Western democratic countries' (2011: 183). He survives the difficult journey to the UN camp, despite 'hav[ing] to go back through Cambodia ... a country he never vowed to see again' to reach 'Kao I Dang refugee camp' (2011: 183-4). Although Kuan (and family) eventually arrive in Australia, and despite embracing his new life in Australia, traces of his time spent in the camps manifest as 'damage incurred [prior to and] by immigration' (Hron 2009: 25). Any recollection of his familial homeland however, soon triggers unwanted traumatic memories of the camps; as the punctum, it becomes a place and site of the wound where the past constantly 'pierce[s]' (Barthes 1981: 26) the present, distorting his behaviour and thoughts:

\section{Father-}

'Australians all let us rejoice, for we are young and free.' This to him was the most beautiful national anthem in the world. There was golden soil and wealth for toil. Who wanted to be anywhere else? In other countries, where their anthems were about rinsing the land in blood of brothers? (Pung 2011: 195) 
In his attempt to erase those 'memor[ies] that [he] had deliberately forgotten to remember', what Kuan fails to realise are how his 'dismembered memories' (2011: 191) or the fragmented distorted memories of the traumascape have been passed on to his daughter, or when they will re-surface (which occurs when he revisits the fields in Cambodia). Of such physically affected sites Tumarkin states that the "trauma is contained not in an event as such, but in the way this event is experienced and reexperienced over time, frequently across generations' (2015: 36), which is precisely what the daughter concludes in her observations of him in his homeland: 'Her Dismemories were small, but her father's were enormous' (Pung 2011: 191).

\section{Cambodia Mis- and Dis-remembered}

In 'Part IV. Cambodia:' (Pung 2011: 189), the father journeys to Cambodia with two of his grown daughters. The trip home is not easy for him and he fights hard against Alice's wish of visiting this place: Father- 'He would never let her go to Cambodia. 'You can travel anywhere in the world except there,' he told her ... but still she would not relent' (2011: 195). The return to the familial homeland for both generations, though difficult, is vital. For survivors who have experienced trauma first-hand and their children, the postgenerations, whose lives have been 'overwhelm[ed] by inherited memories' (Hirsch 2012: 5), there is a need revisit the familial homeland to feel connected with the trauma of their shared past.

However, once back in Cambodia Alice soon realises that her father's old homeland is no longer the place of his childhood as he 'mis-remembers' the city of Phnom Penh where he spent his privileged childhood as a boy:

Father-

When their driver drove him to his old street, he could barely remember it. 'This street used to be so clean and beautiful,' he told his daughters. 'People would sweep out front of their shops every morning, and in the evening pull up chairs and sit outside to chat.' They thought that it was just their father being nostalgic about his former home, which looked like four squares stacked one on top of the other, but he knew that he was not mis-remembering ... (Pung 2011: 205)

His mis-remembered recollections of his happy childhood and home are in contrast to the vivid memories of the camp he was resettled in under the Khmer Rouge, where he was forced to dig holes to bury the dead in the fields. ${ }^{11}$ When the father revisits the camp site, the place transforms into a point of memory; and a palm tree triggers memories of when he witnessed a soldier use it to kill a child. For the daughter whose own life has been shaped by these postmemories, she is forced to confront the site of the trauma head on:

\section{Daughter-}

How do you feel about being here? she had wanted to ask him, but she knew what his answer would be.

Nothing much. It's just a place. 
Yet it wasn't nothing much. It was nothing at all, and yet suddenly this flat stretch of nothing was everything. All that existed at that moment was this space. And she knew all her father's life had been about filling in this emptiness. (Pung 2011: 213-4) ${ }^{12}$

Standing in the Killing Fields in Cambodia, her father 'a man who survived genocide' (Pung 2012: 47) is unable to see what the daughter sees, nor does he comprehend the impact the postmemories of this place has had on both their lives. Since leaving his homeland all he had wanted to do was forget it: 'before he came to Australia, he had done a spring-clean of his mind ... to be sure that when he landed in the new continent, he could start anew' (Pung 2011: 210). His new life as an immigrant to Australia had been about creating a new safe home and shielding his daughter (and her siblings) from the horrors he experienced; erasing that past, blocking out those memories and in a way starting again 'from zero'. In Australia, he professed to wanting 'to whitewash their history', even naming his daughter Alice 'because he believed this new country to be a Wonderland, where anything was possible if only she went along with his unfailing belief' (2011: 194-5). As an immigrant and refugee, he may have felt the need to internalize the conventional image of the successful immigrant' for his family and community; in removing his past he was able to 'play down [the] suffering of immigration ... in their new country ... so as to measure up with the stereotypical fiction of success' (Hron 2009: xiv):

Father-

To live a happy life, he believes, you need a healthy short-term memory, a slate that can be wiped clean every morning, like one of those toys he bought for his daughter ... an Etch A Sketch. If you turned it upside down and shook it, your art disappeared. (Pung 2011: 5)

At the start of the memoir, readers are led to believe that the father has erased his past in order to better assimilate into his new country, yet as the effects of his trauma are triggered and his memories are revealed, this notion is soon called into question. His initial reflections of 'wiping the past and his mind clean' become a painful reminder of the trauma sustained under Pol Pot's regime and the forced indoctrinations on his people, of starting one's life each day 'from Year Zero' (Pung 2011: 116).

\section{Conclusion - Writing Trauma}

With regards to traumascapes, Tumarkin explains that within the 'physical settings of tragedies, both natural and human-made' there exists a 'powerful bond between survivors and the sites of the trauma' (2005: 13-14). For postgeneration writers like Alice Pung, being able to revisit such a site allows her to mourn, remember and understand her own past. As Tumarkin writes what occurred in 'these places, the parts of our pasts that memory cannot fully absorb, and language cannot fully contain [is what continues] to inhabit and refashion the present' (Tumarkin 2015: 36):

\section{Daughter-}

She felt that this country was something precious - as brutal, as split open as a pomegranate, with hot breath and a million red and buried eyes. A country she would 
never understand, but that had shaped her father and made him who he was ... (Pung 2011: 216-217)

Returning to the Cambodian Killings Fields is important for both generations - for the father, he is finally able to share his testimony, and for the daughter, she can begin to process the trauma that occurred there, and in her own way find reconciliation by writing about it. Only by returning and revisiting these familial traumascapes, that the sites are able to 'compel memories, crystallise identities and meanings, and exude power' (Tumarkin 2005:14) especially for postgenerations. For Alice, it is standing in this field, witnessing this place, and hearing her father's testimony in the home country, that his traumatic memories are able to be witnessed and processed to become part of her own present identity and narrative.

\section{Endnotes}

1. 'Dismemory' is termed in Part IV: Cambodia by the daughter when describing her father's trauma which has manifested into his actions, thinking, and behaviour. Pung also refers to it as 'dismemembered memories' and of survivors: 'people in clusters, picking up the pieces' (2011: 191).

2. Hirsch's idea of postmemory examines the intergenerational impact of the passed-on memory of Holocaust survivors onto the "generation after" (sic 2012: 5). Hirsch writes :'My parents' stories and behaviors ... followed a set of conventions that were no doubt shaped by stories we had read and heard, [of] conversations ... [and] fears and fantasies associated with persecution and danger' (sic 2012: 4).

3. The 'Cambodian genocide of $1975-1979$, in which approximately 1.7 million people lost their lives ( $21 \%$ of the country's population), was one of the worst human tragedies of the last century ... [T] he Khmer Rouge regime headed by Pol Pot combined extremist ideology with ethnic animosity and a diabolical disregard for human life to produce repression, misery, and murder on a massive scale' (Cambodian Genocide Program: 2016).

4. Her Father's Daughter (2011) has six sections but four parts: 'Prologue' (3-8), 'Part I. China' (10-38), 'Part II. Melbourne' (39-112), 'Part III. Cambodia: Year Zero' (113-188), 'Part IV. Cambodia' (189-217) and 'Epilogue' (219-238).

5. Writer Rachel Aviv on the effects of trauma and psychic wounds explains how refugees are often 'the purveyors of unique forms of psychological expression'; she sites how in the 1980s 'in California, a hundred and fifty Cambodian women, who'd seen family members tortured during the Pol Pot regime, lost the ability to see' (2017: 75).

6. Cambodian writer and survivor of Pol Pot's regime Chanrithy Him in her award-winning memoir When Broken Glass Floats: Growing Up Under the Khmer Rouge, describes similar 'trigger memories' when recalling the Black Bandits: 'The sight of someone dressed entirely in black would also trigger a memory - the uniforms of the Khmer Rouge. And for a moment it could paralyze me as if under a spell. Watching a documentary on Ethiopia showing children lining up for rations would jolt me back to the muddy fields, to a time when I was as frail and exhausted ... existing only for food. Memories seep back to me in ways I hadn't imagined ...' (2000: 25).

7. Despite Unpolished Gem being written in the 'voice of a twenty-something-year old armed to the teeth with caustic wit and black humour' (Pung 2012: 44), Pung details her mental breakdown as a teenager which she attributed to the pressures of doing well at school. 'I woke up one morning with a false rubber skin on my face ... I could not prise off this rubber deathmask...' (2006: 177). The event leads to question whether this was also symptomatic effect of intergenerational trauma.

8. 'The adult catastrophic trauma state is initiated by the recognition of inevitable danger ... [then] surrendering to it ... the affective state changes from the signal of avoidable danger (anxiety) to a surrender pattern which is the common pattern of 'freezing' or ... 'panic 
inaction' ... it consists of a paralysis of initiative, followed by varying degrees of immobilization ... At the same time, there is a 'numbing' process by which all affective and pain responses are blocked' (sic, Krystal 1995: 80).

9. Laub's extensive studies involved working with journalist Laurel Vlock and recording and listening to Holocaust survivors' stories. 'Giving testimony was the creation of a narrative in which the inconceivable trauma of the survivor was finally externalized and known by both speaker and listener. The listener was an indispensable participant in the process, respecting both speech and silence, serving as the empathetic other [for] many survivors ... Dr. Laub and Ms. Vlock thought they would hear stories of horror and atrocity ... that was only a part of [it]. Events and images were often presented in fragmentary, undigested form ... barely a ... narrative ... as though these imprints had been preserved unchanged and secluded from ... daily conscious life, like nightmares, and the survivor wanted literally to force them onto the listeners in order to rid himself of them ... beyond the anguish and dread ... was the intense yearning to ... be connected with the truth of one's life' (Laub: 1998).

10. Hron explains that ' $f \mathrm{f}$ ]ormer refugees, who experienced persecution, violence, or trauma in their countries of origin often suffer from symptoms of chronic post-traumatic stress disorder ... including depression, self-injury, disassociation, depersonalization, isolation and persistent mistrust' (2009: 29).

11. With their takeover in April 1975, the Khmer Rouge forced most of the population out of Phnom Penh into the countryside ... large numbers either died because of hardship or were executed ... Under the Khmer Rouge, the entire social structure of the country suffered radical and massive changes. An estimated 1 ... to 2 million Cambodians died during the first threeand- [a] half years of communist rule. Traditional family life was violently disrupted and virtually abolished between 1975 and 1979 [with n] uclear families ... broken up and ... replaced with communal groupings ... About 97[\%] of the population was forced into communal economic programs. Urban dwellers were driven into the countryside in mass marches that caused great suffering and many deaths' (2016).

12. A photo of Pung's father Kuan and her sister Alison at the Killing Fields appears in Westerly (2012: 45). 


\section{Works cited}

Aviv, Rachel 2017 'The Trauma of Facing Deportation’ The New Yorker April, 68-77

Barthes, Roland 1981Camera Lucida: Reflections of Photography New York: Hill and Wang

'Cambodia - Society', Federal Division of the Library of Congress: The Country Studies Series, 19881999, at http://www.mongabay.com/reference/country studies/cambodia/SOCIETY.html (accessed April 2017)

'Cambodian Genocide Program: The CGP, 1994-2015', Genocide Studies Program, 20 Dec, at http://gsp.yale.edu/case-studies/cambodian-genocide-program (accessed April 2017)

Caruth, Cathy et al 1995 Trauma: Explorations in Memory Baltimore: The John Hopkins University Press

Caruth, Cathy 2014 Listening to Trauma: Conversations with Leaders in the Theory and Treatment of Catastrophic Experience Baltimore: John Hopkins University Press

Him, Chanrithy 2000 When Broken Glass Floats: Growing Up Under the Khmer Rouge New York: W. W. Norton \& Company

Hirsch, Marianne 1997 Family Frames: Photography, narrative and postmemory Cambridge: Harvard University Press

Hirsch, Marianne 2008 ‘The Generation of Postmemory’ Poetics Today 29.1, 103-128

Hirsch, Marianne 2012 The Generation of Postmemory: Writing and Visual Culture After the Holocaust New York: Columbia University Press

Hirsch, Marianne and Leo Spitzer 2012 'What's Wrong with This Picture?'in M Hirsch The Generation of Postmemory: Writing and Visual Culture After the Holocaust New York: Columbia University Press, 55-78

Hirsch, Marianne and Leo Spitzer 2012 'Testimonial Objects?'in M Hirsch The Generation of Postmemory: Writing and Visual Culture After the Holocaust New York: Columbia University Press, 177-202

Hron, Madelaine 2009 Translating Pain: Immigrant Suffering in Literature and Culture Toronto: University of Toronto Press

Krystal, Henry 1995 'Trauma and Aging: A Thirty-Year Follow-Up' in C Caruth (ed) Trauma: Explorations in Memory Baltimore: The John Hopkins University Press, 76-99

Laub, Dori 1995 'Truth and Testimony: The Process and the Struggle' in C Caruth (ed) Trauma: Explorations in Memory, Baltimore: The John Hopkins University Press, 61-75

Laub, Dori 1998 'Bearing Witness to the Holocaust' Reaching out into the Jewish Community September, at http://www.holocausttestimonies.com/mainframe.htm (accessed April 2017)

Laub, Dori 2014 'A Record That Has Yet to Be Made: An Interview with Dori Laub (June15-16, 2013, Woodbury, Connecticut) in C Caruth Listening to Trauma: Conversations with Leaders in the Theory and Treatment of Catastrophic Experience Baltimore: John Hopkins University Press, 47-78

Pung, Alice 2011 Her Father's Daughter Melbourne: Black Inc.

Pung, Alice 2006 Unpolished Gem Melbourne: Black Inc.

Pung, Alice 2012 'Writing about my Father in Her Father's Daughter' Westerly 57 (2), 41-47.

Tumarkin, Maria 2005 Traumascapes: The Power and Fate of Places Transformed by Tragedy Victoria: Melbourne University Press

Tumarkin, Maria 2015 'No Skin’ Griffith Review Writers Prize 2015, 147-173

Tumarkin, Maria 2015 'Traumascapes Revisited’ Artlink 35 (1), 34-39 